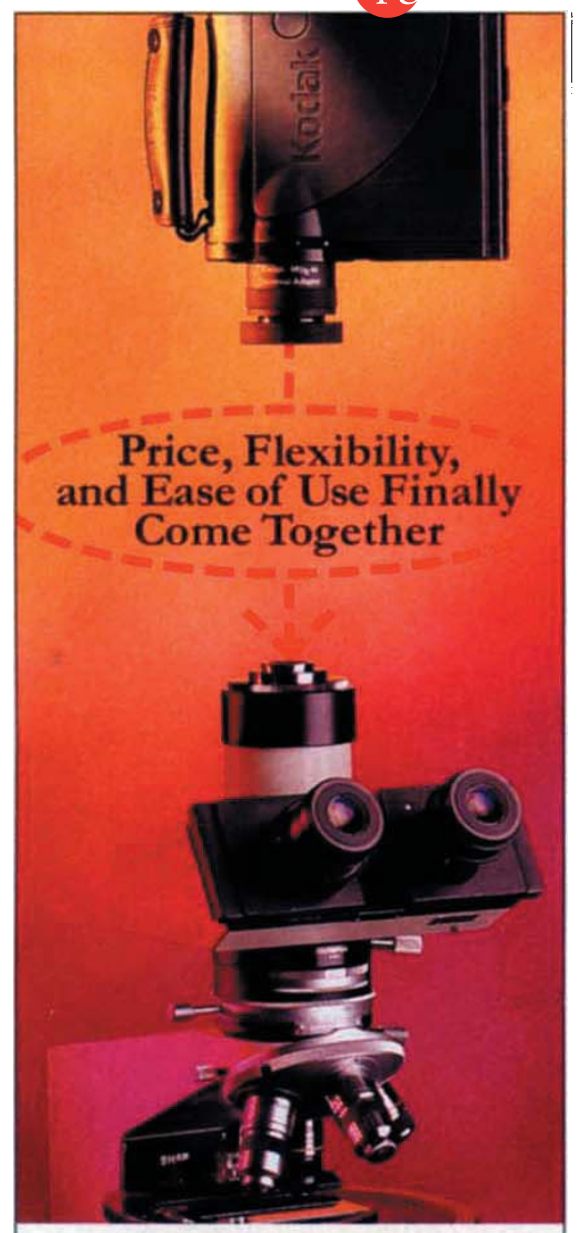

Introducing the Kodak Digital Science Microscopy Documentation System 40 (MDS 40)

Plug-and-play simplicity lets you start acquiring images within minutes.

With more pixels than video, plus 24-bit color, it really performs.

And you can use the MDS 40's Kodak Digital Science DC40 camera for other imaging applications.

Visit our web site at www.kodak.com/go/scientific, or call us at 1-800-225-5352 (or 1-716-722-5813).

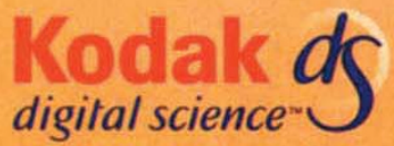

\title{
Minnows and academics hold up EPA rules
}

After years of delay, officials at the US Environmental Protection Agency (EPA, Washington, DC) insisted during a public meeting in July that they will soon-before the end of 1997-implement rules for regulating biotechnology-derived plant pesticides. Nearly issued several times already, the rules have been most recently held up following questions raised by academic researchers and representatives from small companies. These groups say the proposed rules are onerous and will hamper their freedom to do research and develop new noncommodity agricultural and ornamental plant products.

The proposed rules are being issued under the US Federal Insecticide, Fungicide, and Rodenticide Act (FIFRA), one of several major statutes governing EPA operation. Although the FIFRA rules have been under development, agency officials have been regulating plant pesticidal products such as commodity crops engineered to produce insecticidal proteins from Bacillus thuringiensis $(\mathrm{Bt})$ on a caseby-case basis. By now, Bt proteins, as well as a class of proteins that interfere with viral plant pathogens, are broadly exempt from most additional agency scrutiny.

The EPA developed the FIFRA proposals as part of a broader strategy for adapting rules to fit existing federal statutes. This strategy, which took shape during the mid1980 s as the "coordinated framework" for dealing with biotechnology, meant that Congress did not have to craft specific new laws for this purpose. More than once, however, this strategy has caused outcry among academic researchers and industry representatives. Now some of them are chafing because the latest EPA draft rules adapt FIFRA to fit plants that are genetically engineered (or, conceivably, modified by other technologies) to produce pesticidal products.

"[Scientists] need to accept the fact that EPA is required under law to regulate any substance intended and marketed as a plant pesticide," says Lynn Goldman, EPA assistant administrator for prevention, pesticides, and toxic substances. "We need to have rules, but also want [to designate] broad categories of exemption while targeting those plant pesticides with potential for greater than negligible risk."

"It's a real jolt to learn our products are classified as pesticides," says John Sanford of Cornell University (Ithaca, NY). Sanford is the inventor of the "biolistics" technique for blasting DNA into cells. Monsanto (St. Louis, $\mathrm{MO}$ ) now owns the rights to that technology for crop transformation. Sanford is running Sanford Scientific, Inc. (Ithaca, NY), a small, family-owned enterprise for developing and marketing ornamental plant varieties. "Scientists like things that make sense, so the scientific community is really upset with EPA." He says his company plans to engineer flowering plants and grasses with genes to make pesticides that are safer for consumers to handle than many of the chemical products now being marketed.

EPA officials estimate that regulatory costs could range widely from $\$ 60,000$ to $\$ 1$ million or more per major plant pesticide product. This is a large amount for a small business, but Sanford insists that "the real costs [of regulations] are greater than EPA estimates. Extending development time and the uncertainty factor are incredibly important when raising capital and deciding what projects to do. The high costs are enough to make us drop all efforts to create alternative pesticides."

Roger Beachy of the Scripps Institute (La Jolla, CA), pioneer of the virus coat protein approach to conferring resistance to plant virus diseases, is also unhappy about the proposed rules: "They will take away my ability to invent because of the high cost in a small market with low profit margins," he says. Anne Vidaver, a plant pathologist at the University of Nebraska (Lincoln, NE), adds that the rules affect not just businesses "but also universities and crop improvement associations." Moreover, she feels that the focus of the rules has been on products with hypothetical rather than proven risks for health or the environment.

Not everyone in the academic and business sectors agrees with these complaints. "As a member of the Biotechnology Industry Organization (BIO; Washington, DC), we worked on comments supporting the EPA plant pesticide rules," says Joseph Panetta of Mycogen (San Diego, CA). "EPA has put together a process that recognizes the concerns of small companies. If products are benign, there's an opportunity to consider them as benign, and it doesn't take five to ten years to take a product to market. It's not as black a picture."

"It's not our intention to stifle creativity," says Janet Andersen from the EPA Office of Pesticide Programs. "Our mandate is to protect the food supply and the environment. We hope to convince the American people that the technology is safe and to ensure it's accepted."

Jeffrey L. Fox 